\title{
Regional features of legislative framework for environmental security of the Russian Federation
}

\author{
Elena Voskresenskaya $^{1,{ }^{*}}$, Lybov Vorona-Slivinskaya ${ }^{2}$, Dmitry Mokhorov ${ }^{1}$ and Alexander Tebryaev ${ }^{1}$ \\ ${ }^{1}$ Peter the Great St.Petersburg Polytechnic University, 195251, St. Petersburg, Polytechnicheskaya \\ str., 29, Russia \\ ${ }^{2}$ Saint Petersburg State University of Architecture and Civil Engineering, 190005, St. Petersburg, 2nd \\ Krasnoarmeyskaya str., 4, Russia
}

\begin{abstract}
The article addresses the problem of the current environmental crisis, which threatens the sustainable development of human civilization. As a result of further degradation of natural systems, the biosphere gets destabilized and loses its integrity, the large areas get devastated, and the quality of the environment necessary for life becomes unstable. The crisis can be overcome only by building a relationship of the human and the nature which does not leave room for destruction and degradation of the natural environment. Thus, scientific research, analysis and search for solutions to legal problems of ensuring environmental security in the regions of the Russian Federation acquire special relevance and practical significance and are the objectives of this work. Without theoretical understanding and scientific research of the elements of this system and, first of all, the regional system of legislative framework for environmental security and its features in the field of governance, it is impossible to achieve the necessary interaction of federal and regional systems and to solve the problem, since there remain fundamental causes and sources that generate the whole range of threats to ecological security.
\end{abstract}

\section{Introduction}

The existing approaches to handling a vital problem of ensuring human security and the foundations of human life are ineffective, used only in part (if at all) and therefore are unable to solve it. A theoretical study of the problem under consideration is vital for the implementation of relevant environmental programs and for the effective operation of the system of public authorities and all management structures, and, consequently, for the protection of individual and citizen rights and freedoms.

Until now, the main causes and sources of environmental threats remain unknown, as well as the sources that reproduce this phenomenon in the environment and often in public life. Public administration of this area has not yet developed a unified approach to solving such a significant problem. In recent years, many attempts have been made to study its individual aspects [1-4], but the problem as a whole remains insufficiently studied,

\footnotetext{
${ }^{*}$ Corresponding author: elenvoskr@mail.ru
} 
especially its regional features [5-13]. Hence, there emerged an objective need for a deep study of existing problems of legislative framework for environmental security in Russia [14-16].

\section{Materials and Methods}

Legal regulation of the group of public relations in question (regional features of the legislative framework for environmental security of the country) relates to more than one branch of law, which required an integrated approach to the problem. The study of regional features of the legislative framework for environmental security of the Russian Federation is a crucially important matter of theoretical and practical significance.

The categories "security", "national security", "regional environmental security of Russia" are the parts of a single social system - the security system. The authors agree with researchers who point to the predominantly regional nature of state environmental protection administration, but note that ensuring environmental security can hardly be considered in such a way due to the exceptional importance of the problem and to the predominantly federal nature of the regulation of this group of public relations.

The authors studied the concepts of "nature conservation", "ensuring environmental security", "ensuring nature conservation", "public administration of environmental security and environmental protection." As a result, the authors concluded that ensuring environmental security is being unreasonably reduced to nature conservation. These concepts are closely related, in some aspects coincident, but still not identical. Ensuring environmental security differs from nature conservation in the following aspects: a) the possibility of protecting the objects (in the case of ensuring environmental security their protection must be fully guaranteed); b) the degree of protection (respectively, the highest); c) forces and assets involved in the protection (respectively, all available in the state, including those capable of conducting combat operations); d) the actors of the implementation (respectively, structures with broad higher-level powers and, above all, security agencies); e) the forms and methods of their activities (respectively, entirely legal forms, mandatory method); $\mathrm{f}$ ) the purpose of protection (respectively, the preservation of the object by any means, including the use of force), and others. The authors defined environmental security not only as a state of protection (or lack of threats), but also as a system of restraining and offensive forces and defensive structures intended to resist any aggressor (or potential aggressor) of the objects of protection (this system created in the state, region, world). This is an indicator of the state of protection of the protection object and a criterion for assessing the quality of the object's protection system and the quality of the state of the object in the environment.

Based on the analysis of the Federal Law "On Environmental Protection", the authors identified three types of environmental security: natural security (the security of the pristine nature), natural-anthropogenic security (security of the environment altered by man) and anthropogenic security (security against man-made objects that pose a threat), which the authors believe to be insufficiently regularized since not all types of security are revealed and system-forming types are not identified.

\section{Results}

Law "On Security", we will present a multilevel structure of environmental security with the following main elements: object of protection; threats to vital interests; system of security measures (security guarantees); state policy as a set of concepts that ensure the state of protection; security system as a set of organizationally and functionally interrelated 
elements whose activities are aimed at implementing measures to ensure environmental security (governance and security entities).

In the opinion of the authors, "the law of emergency situations" is a regulator of the state (relations) for protecting the population and territories from emergencies (calamities, accidents, disasters). "Environmental security" is a state that reflects the regulatory potential and the actual implementation of another (broader in scope) law, referred to as "the law of ensuring environmental security (life support, safe living of the population)", which includes both the said relations and the relations of the negative impact of environmental pollution due to the current human activities and pollution accumulated in nature due to the antecedent human activities, as well as the relations of the protection against environmental crimes, which indicates categories close in the framework of environmental law, but not identical. "The law of emergency situations" is the part of "the law of ensuring environmental security", which in turn is the part of ensuring "the right to a favorable environment", guaranteed by the Constitution of the Russian Federation (Article 42).

Security problems and the right of citizens to a favorable environment are inextricably linked. "Environmental security" is a state that provides an ecological balance in the environment which avoids vital damages to the environment and humans. Hence "ensuring environmental security" is an activity to achieve such a state. The latter is closely connected with the environmental rule of law, which is indispensable for overcoming the decrease in the quality of the environment under the influence of natural and man-made threats, threats from environmental crimes, past and present anthropogenic activities.

Proceeding from the study of legal acts, the authors draw the following conclusions:

- The federal legislation on ensuring environmental safety in Russia is extensive, diverse and develops within all areas of human activity yet its development is spontaneous and uncoordinated. It does not have a unified and coherent terminology; the system-forming act is not adopted; it requires recognition, formation and systematization. It would be advisable to systemize the rules regulating this sphere in the form of "Fundamental principles of the Environmental Legislation of the Russian Federation", highlighting environmental protection, the use of natural resources and ensuring environmental safety. Legislation has not yet become a solid basis for the development of regional legislative systems.

- The studied legislation has an inter-industry nature, although it is not considered the basic safety legislation, does not separated from environmental legislation, whose declared norms do not have mechanisms for its implementation. It requires recognition as an integral part of national security and the isolation of the sub-sector in environmental law.

- In the Concept of National Security of the Russian Federation [17], it is necessary to show the priority of not the economic, but the environmental component, since the last is basic, therefore when problems of this component are solved, success in all spheres of human life is inevitable.

- The authors propose to classify the environmental rights of a person by the criterion of their importance as follows: a) "life-forming" (gene pool, life, favorable environment), b) "life-supporting" (health, environmental safety, choice of a doctor and medical institution, compensation for health and property (except for natural objects) and nature of the environmental offense), c) "other" (the right for environmental information).

- Distinctive features of environmental threats to the constituent entities of the Russian Federation are the saturation of raw materials, large areas with exceptionally low population density, which has become an "attractive force" for the illegal use of natural resources by foreign entities; the role of a "raw materials appendage" within the country and in the world economy; the growing pace of the regions lagging behind the countries building the post-industrial society; steady depletion of natural resources; the replacement of the native population with emigrants due to migration of the local population; proximity of state borders of eight regions of the federal district. There are also actual threats - 
transport accidents, fires, explosions, collapse of buildings and structures; disasters with the release of radioactive substances at nuclear cycle facilities, release of chemically and biologically hazardous substances; location of industrial facilities in residential areas and others.

The authors propose to divide regional environmental safety measures into environmental safety measures (all measures to ensure human life activities) and environmental safety measures (special measures that protect the environmental system from destruction).

\section{Discussion}

Let us classify the environmental threats to Russia: a) according to the level of threats international, federal, regional (including local and object-based); b) according to the source of threats - internal (emerging inside Russia), external (originating from the outside, international); c) according to the object of threats - to the security of the individual, society, state (which includes threats to a human); to the security of the environment and its elements, including nature; d) according to the areas of threats - to the economic, scientific and technological, military, social, information, environmental, etc. security.

The Russian Federation Law "On Security" and the Federal Law "On Environmental Protection" do not contain provisions on this issue; the specific legislation is fragmented, insufficiently regulating environmental threats and not introducing effective mechanisms for their prevention and elimination. Two kinds of threats are legislated: external (originating from abroad) and internal (emerging inside the country), posing a danger to the vital interests of the objects of protection. It is necessary to regulate the following kinds of threats: man-caused (created by human activities) and natural (created by the nature); primary and secondary (created by previously contaminated nature).

The study of statistics on the problem in question in the regions of Russia shows that the current system of environmental security is not effectively solving the tasks assigned, because it lacks integrity, is insufficiently organized and inefficiently managed. For example, in the first half of 2018, the monitoring services of the natural environment recorded 39 cases of extremely high and high air pollution; 2 cases of accidental air pollution; 1432 cases of extremely high and high pollution of water bodies; 10 cases of accidental pollution of water bodies; 4 cases of accidental soil pollution. Table 1 presents the main indicators characterizing the impact of economic activity on the environment and natural resources [18].

Table 1. The main indicators characterizing the impact of economic activity on the environment and natural resources.

\begin{tabular}{|c|c|c|c|}
\hline Indicator & 2014 & 2015 & 2016 \\
\hline $\begin{array}{c}\text { Emissions of air pollutants - total, } \\
\text { million tons, including: }\end{array}$ & $\mathbf{3 1 . 2}$ & $\mathbf{3 1 . 3}$ & $\mathbf{3 1 . 6}$ \\
\hline $\begin{array}{c}\text { - from stationary sources } \\
\text { - from mobile sources - total, } \\
\text { including: }\end{array}$ & 17.5 & 17.3 & 17.3 \\
$\quad \begin{array}{c}\text { from motor transport; } \\
\text { from railway transport }\end{array}$ & 13.6 & 14.0 & 14.3 \\
\hline $\begin{array}{c}\text { Capture and neutralization of air } \\
\text { pollutants from stationary sources, } \\
\text { million tons }\end{array}$ & 54.1 & 52.0 & 14.1 \\
\hline $\begin{array}{c}\text { Withdrawal of water from natural water } \\
\text { sources for use, billion m }\end{array}$ & 63.2 & 60.8 & 615 \\
\hline
\end{tabular}




\begin{tabular}{|c|c|c|c|}
\hline $\begin{array}{l}\text { Loss of water during transportation, } \\
\text { billion } \mathrm{m}^{3}\end{array}$ & 7.7 & 6.8 & 6.8 \\
\hline Water recycling and reusing, billion $\mathrm{m}^{3}$ & 136.6 & 138.9 & 137.9 \\
\hline Water exploitation index (WEI), $\%$ & 1.52 & 1.46 & 1.48 \\
\hline $\begin{array}{l}\text { Average daily water supply to the } \\
\text { population and budget organizations per } \\
\text { city resident, liters }\end{array}$ & 150.0 & 145.2 & 143.0 \\
\hline $\begin{array}{l}\text { Proportion of the population provided } \\
\text { with low-quality drinking water in } \\
\text { respect to the total population, } \%\end{array}$ & 6.8 & 6.3 & 5.8 \\
\hline $\begin{array}{l}\text { Discharge of contaminated waste water, } \\
\text { billion } \mathrm{m}^{3}\end{array}$ & 14.8 & 14.4 & 14.7 \\
\hline $\begin{array}{l}\text { Generation of production and } \\
\text { consumption wastes, million tons, }\end{array}$ & 5168 & 5060 & 5441 \\
\hline $\begin{array}{l}\text { including: } \\
\text { - dangerous } \\
\end{array}$ & 124 & 110 & 98 \\
\hline $\begin{array}{l}\text { Use and neutralization of production and } \\
\text { consumption wastes, million tons }\end{array}$ & 2357 & 2685 & 3244 \\
\hline Reforestation, thousand hectares & 863 & 803 & 840 \\
\hline $\begin{array}{c}\text { Protection of forests against harmful } \\
\text { organisms by biological method, } \\
\text { thousand hectares }\end{array}$ & 208.8 & 196.1 & 379.9 \\
\hline $\begin{array}{c}\text { Protection of forests against harmful } \\
\text { organisms } \\
\text { by chemical method, thousand hectares }\end{array}$ & 84.4 & 36.6 & 20.6 \\
\hline
\end{tabular}

Table 2 presents the main indicators characterizing the impact of economic activity on the environment and natural resources main indicators characterizing the impact of business activities on environment by constituent entities [18].

Table 2. The main indicators characterizing the impact of economic activity on the environment and natural resources main indicators characterizing the impact of business activities on environment by constituent entities of the Russian Federation in 2017.

\begin{tabular}{|c|c|c|c|c|c|}
\hline Indicator & $\begin{array}{c}\text { Water } \\
\text { withdrawal } \\
\text { from natural } \\
\text { water } \\
\text { reservoirs } \\
\text { for practical } \\
\text { use1), } \\
\text { mln.cu. }\end{array}$ & $\begin{array}{c}\text { Recycled } \\
\text { and } \\
\text { consistent } \\
\text { use of } \\
\text { water1), } \\
\text { mln.cu. m }\end{array}$ & $\begin{array}{c}\text { Discharge } \\
\text { of } \\
\text { polluted } \\
\text { sewage 1), } \\
\text { mln.cu. m }\end{array}$ & $\begin{array}{c}\text { Emission } \\
\text { of } \\
\text { pollutants } \\
\text { into } \\
\text { atmospher } \\
\text { e from } \\
\text { stationary } \\
\text { sources, } \\
\text { thou. } \\
\text { tonnes }\end{array}$ & $\begin{array}{c}\text { Atmospheri } \\
\text { c pollutants } \\
\text { captured } \\
\text { and } \\
\text { neutralized, } \\
\text { thou. } \\
\text { tonnes }\end{array}$ \\
\hline $\begin{array}{c}\text { Russian Federation } \\
\text { - total, }\end{array}$ & $\mathbf{9 8 7 5 2}$ & $\mathbf{1 3 8 6 7 6}$ & $\mathbf{1 3 5 8 9}$ & $\mathbf{1 7 4 7 7 . 5}$ & $\mathbf{5 0 7 4 0 . 6}$ \\
\hline $\begin{array}{c}\text { Central Federal } \\
\text { District }\end{array}$ & 9107 & 40211 & 3143 & 1546.0 & 5319.9 \\
\hline $\begin{array}{c}\text { Northwestern Federal } \\
\text { District }\end{array}$ & 9814 & 11235 & 2772 & 1914.8 & 5776.9 \\
\hline $\begin{array}{c}\text { Southern Federal } \\
\text { District }\end{array}$ & 9573 & 9041 & 1264 & 909.5 & 2625.0 \\
\hline $\begin{array}{c}\text { North Caucasus } \\
\text { Federal District }\end{array}$ & 9450 & 908 & 358 & 148.1 & 480.2 \\
\hline Volga Federal District & 7358 & 29265 & 2251 & 2454.4 & 4589.8 \\
\hline
\end{tabular}




\begin{tabular}{|c|c|c|c|c|c|}
\hline Ural Federal District & 5442 & 25678 & 1515 & 3840.4 & 10510.9 \\
\hline $\begin{array}{c}\text { Siberian Federal } \\
\text { District }\end{array}$ & 7350 & 15870 & 1640 & 5763.7 & 18012.4 \\
\hline $\begin{array}{c}\text { Far Eastern Federal } \\
\text { District }\end{array}$ & 1658 & 6464 & 647 & 900.6 & 3425.5 \\
\hline
\end{tabular}

Table 3 shows the costs of environmental protection in Russia [18].

Table 3. Expenses for environmental protection in Russia, mln rub.

\begin{tabular}{|c|c|c|c|}
\hline $\begin{array}{c}\text { Indicator } \\
\begin{array}{c}\text { Expluding in the following environmental } \\
\text { activities: }\end{array}\end{array}$ & $\mathbf{5 8 2 1 2 8}$ & $\mathbf{5 9 0 8 6 5}$ & $\mathbf{6 5 7 0 2 4}$ \\
\hline $\begin{array}{c}\text { - air protection and climate change } \\
\text { mitigation }\end{array}$ & 102765 & 102307 & 122458 \\
\hline - collection and treatment of wastewater & 234112 & 235553 & 238459 \\
\hline - waste management & 68482 & 66652 & 79517 \\
\hline $\begin{array}{c}\text { - protection and rehabilitation of land, } \\
\text { surface and groundwater }\end{array}$ & 37952 & 44535 & 33608 \\
\hline $\begin{array}{c}\text { - conservation of biodiversity and } \\
\text { protection of natural areas }\end{array}$ & 44593 & 35926 & 42525 \\
\hline - other & 94224 & 105891 & 140457 \\
\hline $\begin{array}{c}\text { - Expenditures on environmental } \\
\text { protection as a percentage of GDP }\end{array}$ & 0.7 & 0.7 & 0.7 \\
\hline
\end{tabular}

The created system of state administration of the area in the regions of the federal district is inefficient. It includes authorities of general, sectoral, intersectoral competence, the forms of which do not follow a unified framework and depend on the historical, national, natural and other characteristics of the regions.

The following functions are recognized to be the main functions of public administration in the environmental field: organization; creation of subordinate laws; coordination of environmental management and nature protection; management of natural resources; planning; environmental regulation, examination, licensing, audit, control, supervision; monitoring of the state of the environment and its changes; accounting of natural resources, the environment as a whole, harmful impacts on them; ecological education; administrative settlement of disputes on the right to resource use, on environmental protection, which is partly characteristic of ensuring environmental safety, but not identical to it. The main function of environmental security is the protection function (the function of law enforcement), which is the system-forming (basic) function.

\section{Conclusions}

The most significant problems of the modern federal legislation are the following: complexity, inconsistency, inadequate development of environmental security relations, which hampers the development of legislation and the practical implementation of existing legal rules; lack of a uniform understanding of the categories of "environmental security", "ensuring environmental security", their use in the rule-making process; the denial by the supreme authority of environmental security as part of the national security of Russia; non-recognition by the state and society of the priority role of this legislation for the development of society and preservation of life on Earth; absence of uniform approaches of departments and other structures to understanding and solving the problem; absence of system-forming law; the predominantly subordinate nature of regulation of relations, which does not correspond to the significance 
of the problem; insufficient correlation of legislation with other levels (international, regional, local).

It is advisable to systematize the norms of this area in the form of the "Fundamentals of the Environmental Legislation of the Russian Federation", identifying separately environmental protection, the use of natural resources and environmental security. The legislation has not yet become a solid basis for the development of regional legislative systems. The legislation has a cross-sectoral nature, however, it is not recognized to be the basic legislation on security, nor is it separated from the legislation on environmental protection, in which the declared rules do not have mechanisms for its implementation; it requires environmental security to be recognized as an integral part of national security and the corresponding sub-sector to be separated in environmental law.

The correlation of legislation of different levels (international, federal, regional) is insufficient, whereas it should be the basis for the elaboration and adaptation of legal rules and principles for the development of regional legislation, which requires their coordination and closer interaction.

Regional features of legislative framework for environmental security of the subjects of the federal district are the following:

- the predominant participation of state bodies of federal subordination with higher-level powers;

- insufficient consideration of interests of the regions and the population of territories, frequent neglect of these interests;

- the protective nature of the activities of regional authorities in solving security problems.

\section{References}

1. E.A. Maltseva, Gosudarstvennaya ekologicheskaya ekspertiza: problemy i protivorechiya deystvuyushchikh norm prirodookhrannogo zakonodatel'stva 2, 19-32 (2014)

2. M.V. Matveeva, Ekologicheskaya ekspertiza kak etap razvitiya lend-developmenta 4, 33-36 (2013)

3. S.I. Sai, Gosudarstvennaya ekologicheskaya ekspertiza v Rossii: stanovlenie, razrushenie, vozrozhdenie 6, 16-20 (2014)

4. D. Khustov, Problemy pravovogo regulirovaniya ekologicheskoy ekspertizy na sovremennom etape 5, 29-44 (2012)

5. E. Voskresenskaya, V. Snetkov A. Tebryaev, Z. Askarov, MATEC Web of Conferences 106, 08055 (2017)

6. E. Voskresenskaya, V. Snetkov, A. Tebryaev, E3S Web of Conferences 33, 03051 (2018) doi.org/10.1051/e3sconf/20183303051

7. E. Voskresenskaya, L. Vorona-Slivinskaya, E3S Web of Conferences 33, 03052 (2018) https://doi.org/10.1051/e3sconf/20183303052

8. E. Voskresenskaya, D. Mokhorov, A. Tebryaev, Matec Web Of Conferences 170, 01058 (2018) DOI https://doi.org/10.1051/matecconf/201817001058

9. E. Voskresenskaya, N. Zhilskiy, E. Shariapova, Matec Web Of Conferences 170, 01057 (2018) DOI https://doi.org/10.1051/matecconf/201817001057

10. P.K. Sun, L. Vorona-Slivinskaya, E. Voskresenskaya, IOP Conference Series: Earth and Environmental Science 90 (2017) https://doi.org/10.1088/1755-1315/90/1/012073 
11. E. Voskresenskaya, L. Vorona-Slivinskaya, S. Panov, MATEC Web of Conferences 193, 02025 (2018) doi.org/10.1051/matecconf/201819302025

12. E. Voskresenskaya, L. Vorona-Slivinskaya, A. Loiko, Constitutional-legal issues of ensuring environmental safety in modern Russia 8(19), 57-59 (2018)

13. E. Voskresenskaya, L. Vorona-Slivinskaya, A. Loiko, Economic and legal problems devastated territories in the russian federation 7(18), 62-65 (2018)

14. V.N. Burkov, A.V.Schepkin, Ecological safety (2003)

15. O.E. Aksiutin, Ecological safety of construction and operation of underground storage of gas and oil products in rock salt (2010)

16. F.S.Astakhov, Environmental safety and efficient nature management (2009)

17. National security concepts of the Russian Federation (2002)

18. Russian Statistical Yearbook 2018: Stat .book (2018) 